\title{
GREEN AREAS IN COASTAL CITIES - CONFLICT OF INTERESTS OR STAKEHOLDERS' PERSPECTIVES?
}

\author{
MATEUS MAGAROTTO, RAQUEL FARIA-DE-DEUS, MONICA FERREIRA COSTA \& ÉRIKA MASANET \\ Centro Interdisciplinar de Ciências Sociais, Universidade Nova de Lisboa, Portugal; Laboratório de Ecologia e \\ Gerenciamento de Ecossistemas Costeiros e Estuarinos, Universidade Federal de Pernambuco, Brazil; Sociologia i \\ Antropologia Social, Facultat de Ciencies Socials, Universitat de Valencia, Spain.
}

\begin{abstract}
Coastal zones have experienced rapid urban growth over the last 50 years and this is expected to continue. The most important reasons for rapid land-use changes are related to real estate pressure and the construction of new urban infrastructures. Coastal systems support a wide variety of social, economic and natural services and are directly affected by multiple human activities. The downside of urban increase is reflected in the change of land-use cover, and land-cover from open areas to built-up areas, especially within the metropolitan cities on the coast. The aim of the paper is to evaluate the relationship between the decrease of large green areas in coastal zones and the efficiency of planning and regulation of those areas. For this purpose, we are presenting a comparison between two case-studies from different countries: Boa Viagem Beach in Recife (Brazil) and Rocha Beach in Portimão (Portugal). These two areas have similar socio-environmental problems. The method relies on two sources: literature review (national regulation and policy documents) and 37 semi-structured interviews with stakeholders/agents responsible for urban development of the two areas of study. The interview questionnaire comprised topics such as the national planning legal framework, the process of urban growth, the impact of densification and the problems related to the lack of green areas in the coastal zones. A 3D GIS model complements the geospatial references of the research, showing the localization of green areas and their decrease over time. The comparison on different aspects of development in the two countries shows that the rules tend to be more efficient in Portugal than in Brazil. However, in both countries, it is felt that more efficient legal instruments and enforcement action is necessary to lead developers to comply with the rules. The use of semi-structured interviews proved to be very effective for comparative analysis on national policies. The paper presents a cross-national perspective with different stakeholders' points of view on the issue of the scarcity of green areas in coastal zones, which is intended to provide helpful information to planners, scholars and administration officers.
\end{abstract}

Keywords: 3D GIS model, green areas, interview, urban planning, vertical growth.

\section{INTRODUCTION}

Cities have always been responsible for the enormous challenges to humans in terms of the adaptations necessary to live in such environments where important ecological services (effluent dilution, clean air, thermal comfort, etc.) need to be managed to promote individual and social wellbeing. However, more recently, the possibility of climate change, demographic aging, and natural resource depletion $[1,2]$ have presented us with new problems. The report of the Department of Economic and Social Affairs of the United Nations in 2012, reports that cites and their surrounding regions used by humans for infrastructure and commerce facilities, require a great many resources, which cause intense pressure on the environment. This is even more worrying because nearly $51 \%$ of the global population live currently in cities and their suburbs. In developed countries like the United States, Canada, Australia, Japan and Europe the estimate is that up to $80 \%$, or even $90 \%$ of the population live in urban centres [3].

Rapid population and urban growth have affected coastal zones around the world, especially in the last decades (from 1970s onwards) [4]. Among the prevailing stakeholders driving extreme urban growth along coastal zones is real estate speculation, which is pushing for the 
construction of more, higher, and more expensive new buildings inside these areas [5, 6]. The view of the passage is more attractive, for the biggest the people and the especial areas for the rest and the vacations.

Another aspect is noted: loss of green areas [7]. If sustainable development practices are to match the pace of rapid changes resulting from urbanisation, the urban knowledge gap must be quickly bridged [2]. Recent literature indicates that green environments within urban areas contribute with multiple benefits, and is very important for the well-being of urban populations [8-10 the provision of urban green areas is approached from a social perspective, as public spaces for recreation and sports activities, regardless of the environmental and economic benefits they can provide from a sustainable development perspective. The planning of urban green areas requires a set of conditions in order to be successful, among which are: an updated regulatory framework, adequate financial resources, technical knowledge of the appropriate plant species and the effective participation of the community. However, without a complete and classified inventory of the existing green areas, any planning is unfeasible.

Rapid urbanization causes tremendous growth in buildings and population that is accompanied by environmental issues including heat islands trapped inside urban areas, including the hinterland of coastal cities. The primary reason for heat islands' formation in urban areas is the absorption of solar radiation by the mass of built-up structures, roads, etc. during daytime [11]. The absorbed heat is subsequently re-radiated to the surroundings and increases ambient temperatures at night [7]. Natural green areas within cities can thus provide a certain adaptability (resilience) to urban landscapes in coping with problems such as increased risks of heat waves and flooding [11]. Green spaces in urban areas have been found to be promising in enhancing urban life quality in many ways, but in many cases this is no longer possible, mainly because of the lack of urban planning. For example, urban-locked natural ecosystems were vastly under-represented in the world's largest assessment of ecosystems [2].

Cities are dependent on the ecosystems beyond their limits, but also benefit from internal urban ecosystems. Such is applicable to urban areas along coastal zones, where part of the city limits is a water mass (the sea or an estuary, for example). These areas are part of the city, both suffering and exerting direct influence over it [7]. Green areas are one of the many possible ecological measures used to combat the problems of urban heating that may also contribute to wider nature and biodiversity conservation. To address the challenges of ecosystems degradation, an interdisciplinary eco-social system approach is critically important and needed at this time [12]. Ecosystems play an important role in facilitating transformations needed to address urban challenges. Understanding how urban ecosystems work, how they change and what limits their performance can add to the general understanding of ecosystem change and governance in an ever more human-transformed world [8, 12].

It should also be noted that green areas provide services that include non-material benefits such as psychological and cognitive advantages to people who are in contact with nature during recreation, aesthetic, spiritual and tourist activities $[2,7,12]$. Therefore, urban-locked 
natural green areas should be one more of the strategies aimed at sustainable development packages of actions, since they confer liveability and resilience in urban areas $[2,7,12]$.

The comparative studies between different countries were made comparing the spacetemporal development of green areas within urban settlements in two different countries: Praia de Boa Viagem Beach at Recife (Brazil) and Rocha Beach at Portimão (Portugal). These two urban areas, although very far apart, have a number of similarities that encourage comparisons from different points of view [4]. In this research, Boa Viagem Beach, located in Recife, northeast region of Brazil, and the Rocha Beach of Portimão located in the southern region of Portugal, Algarve, are taken as case studies for testing the proposed methodology. Two reasons support this choice. Firstly, the findings show that the coastal urban zones of Boa Viagem Beach and Rocha Beach underwent major and rapid physical changes over the 1960-2013 period. Secondly, although these two case studies are located in such distinct geographic contexts, they exhibit similar land-use and land-cover change dynamics especially regarding transitions from non-urban land to urban land. Extensive documental and literature review was allied to 37 semi-structured interviews with stakeholders who were considered responsible for urban changes and development in the two areas of study. The interviews and questionnaire comprised topics such as the national planning legal framework, the process of urban growth, the impact of densification, and problems related to the diminishing green areas in these two coastal cities. A 3D GIS model complements the geospatial references of the research, showing the localization of green areas and their evolution over time.

\section{STUDY AREAS, MATERIALS AND METHODS}

\subsection{Study areas}

Boa Viagem Beach is situated in the coastal area of Recife City, the capital of Pernambuco State, a thriving economy in the Brazilian Northeast (Fig. 1). The study-area is 200 ha and is located in the south of Recife City, with approximately $2 \mathrm{~km}$ of seafront. Due to the
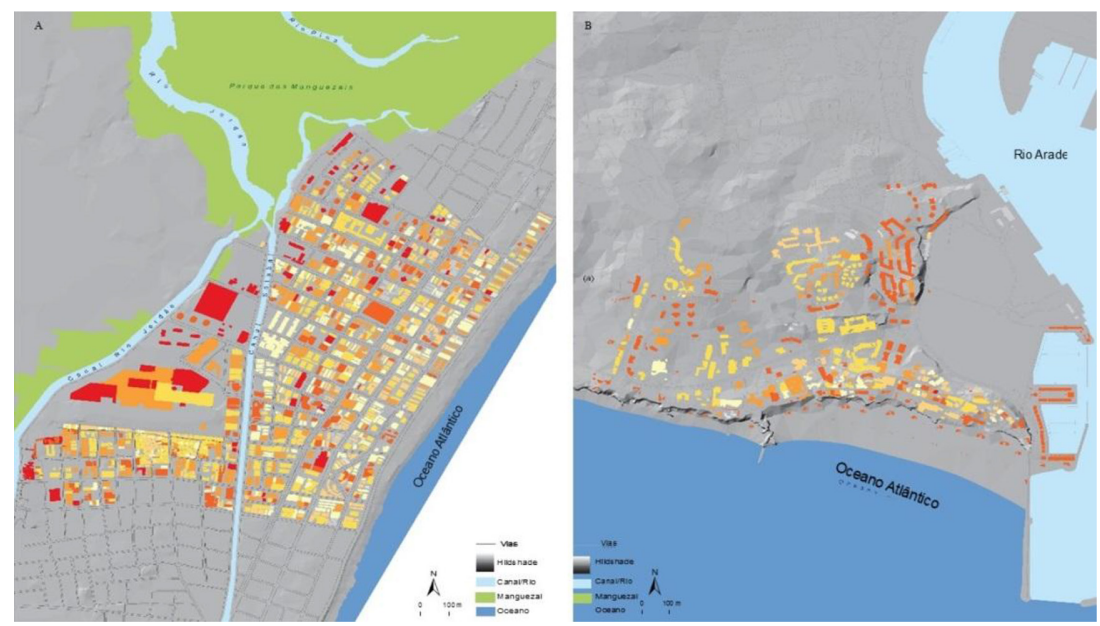

Figure 1: Study areas: (A) Boa Viagem Beach, Recife City, Brazil; (B) Rocha Beach, Portimão, Portugal. 
tropical climate of the region, mangrove-flooded forests dominate the estuaries. As Recife has developed in the last 500 years, especially in the last century, only small fragments of this ecosystem remain. The most important is a park (1000 ha) that limits the landward side of Boa Viagem Beach. It is the only significant green area in the south of the city. Recife City has other green areas such as public parks, communal gardens, and internal courtyards, but the major green area is in the north of the city and is part of the Atlantic Rain Forest (Dois Irmãos Park).

Rocha Beach is situated on the coastal area of the Portimão City in Portugal, and is the capital of Barlavento - Algarve Region (Fig. 1). Located in the Atlantic South of Portugal, the study-area is characterized by a Mediterranean climate. Rocha Beach is 200 ha located in the south of Portimão, with approximately $2 \mathrm{~km}$ of seafront. It has arborized open squares but no public parks. Portimão has other green areas, like public parks, communal gardens, and internal courtyards, but the major quantitative green areas are spread across the city.

The green areas in both cities are diversified by the types of buildings, which include different homes, apartment buildings, commercial buildings and mixed-use buildings. Green areas are considered by UNDESA as an indicator of the quality of life. Based on official data by the town hall of Recife City that measures 'green area per inhabitant', a per capita value of $46 \mathrm{~m}^{2}$ /inhabitant emerges (Table 1).

The World Health Organization (WHO) recommends a minimum of $12 \mathrm{~m}^{2}$ of green area per inhabitant, but the ideal is $36 \mathrm{~m}^{2}$ per inhabitant [3]. The data presented in Table 1, is for the whole Recife City and considers as 'green areas' all types of vegetation cover (trees, grams, bush). This data will be discussed later. In 2012, the Secretariat of the Environment, together with the Environmental Policy Directorate of the Recife City, identified 25 Nature Conservation Units and two Landscape Conservation Units.

No data was found for the Portimão City, but one can follow on the map the distribution of green spaces in Rocha Beach (Fig. 2). As in the city of Recife, Portimão considers all type of vegetation cover as 'green areas.'

\subsection{Materials}

\subsubsection{Cartographic data}

Vector and matrix data were used to identify the green areas in both study areas. Being in different countries, it was necessary to take into account the specific norms and laws that affect these areas (Table 2).

The altimetry data is composed of sets from vector cartography used by the municipality, and the digital terrain model was composed of $1 \mathrm{~m}$ in both areas. It was collected from official sources at the two cities. The representations and digital maps of the areas were made by processing hildshade in Arcgis. Another source of altimetry information was Magarotto et al. (2015). The other set of elevation and contours was obtained from 1:1000 scale altimetry cartography of 1998 , available.

Table 1: Total square meters of green area per inhabitant (annual average) for Recife City

\begin{tabular}{lllll}
\hline City & Year & $\begin{array}{l}\text { Green space in urban } \\
\text { areas }\left(\mathrm{m}^{2}\right)\end{array}$ & $\begin{array}{l}\text { 'Green area per } \\
\text { inhabitant' }\end{array}$ \\
\hline Recife & 2012 & 7156,8158 & 155,5039 & 46,0234 \\
\hline
\end{tabular}

Source: Secretariat of Environment and Sustainability. 


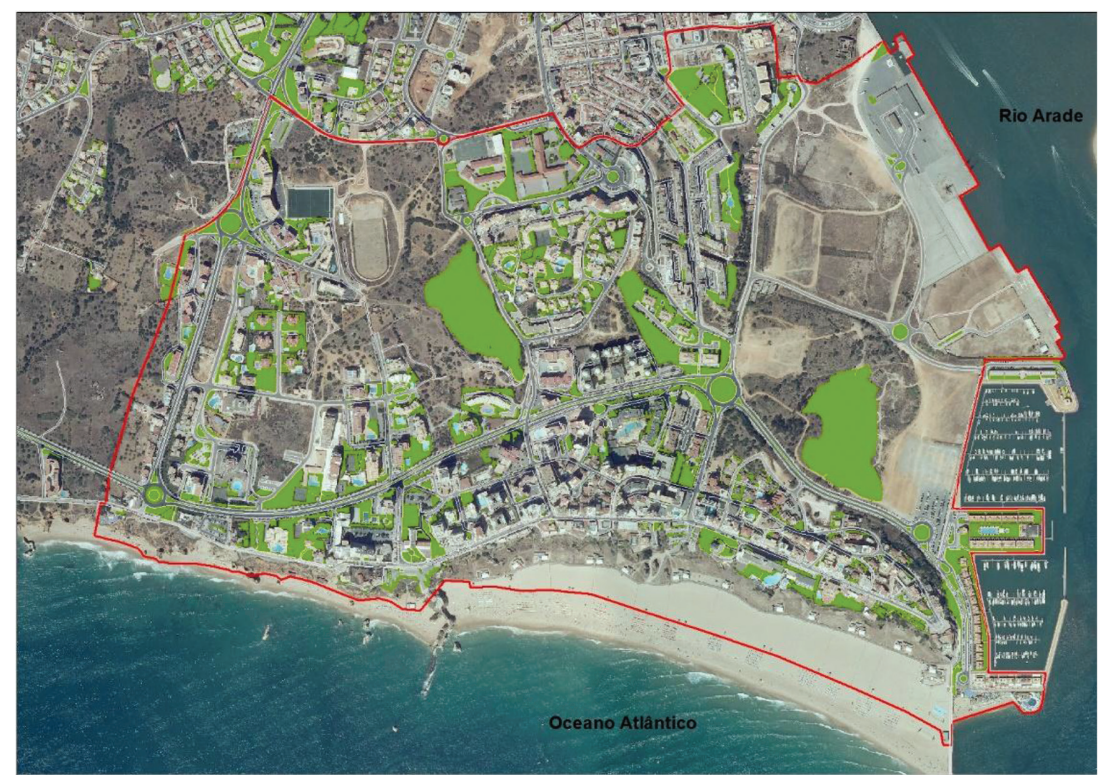

Figure 2: Green areas in study area of Rocha Beach.

Table 2: Vector and matrix data available for each study area.

\begin{tabular}{lll}
\hline City & Data & Year \\
\hline Recife & Aerial photographic covers & 1961 \\
& & 1981 \\
& Satellite images & 2002 \\
& Orthophotomaps & 2013 \\
& Vector cartographic data & 2013 \\
& & \\
& Municipal land use plan & 2008 \\
Portimão & Aerial photographic covers & 1958 \\
& & 1986 \\
& Satellite images & 2002 \\
& Orthophotomaps & 2010 \\
& Vector cartographic data & 2010 \\
& Municipal land use plan & 2008 \\
\hline
\end{tabular}

\subsubsection{Interviews}

Semi-structured interview with key participants is a research technique used with interest groups to assess the current situation of green areas in the two study areas. In conjunction with the interviews, laws and urban development plans were also analysed. These semistructured interviews were carried out by those in charge of town planning, eligible public positions, real estate entrepreneurs, associations/residents and researchers that characterize 
Table 3: Interviews with key informants.

\begin{tabular}{|c|c|c|c|c|c|}
\hline Cities & Researchers & Municipal staff & Politician & Residents Owners & Real estate agents \\
\hline Recife & 4 & 6 & 2 & 4 & 2 \\
\hline Portimão & 5 & 7 & 3 & 2 & 2 \\
\hline
\end{tabular}

interest groups. There was a total of 37 interviews, 18 in Recife (Brazil) and 19 in Portimão (Portugal), with representatives of different groups of stakeholders acting in different aspects of stakeholder's urban growth and built-up areas (Table 3).

The interviews were coded as Interviewee Boa Viagem Beach (IBVB) followed by a number $(1,2,3 \ldots)$; Interviewee Rocha Beach (IRB) and a number. The application of this qualitative technique of social research allowed us to identify and explore the different perceptions and opinions of the stakeholders on the problem, the potentialities and challenges associated with green areas in the two study areas, as well as their impact on urban environment as a whole. It should also be noted that analysis of different discourses has brought to light good practices, points of convergence, and possibilities for understanding the efficiency of green areas to improve the quality of life of local residents and visitors.

All the interviews were recorded in digital format and later transcribed for treatment and analysis.

\subsection{Methods}

The methodological proposal of this paper is the association between qualitative and quantitative research methods, a seldom-attempted approach. The quantitative aspect is the visual analysis of satellite and other images that identified the green areas within each parcel of 200 ha under investigation, and the qualitative aspect is the association of the GIS data with the interviewers' references to green areas they know of. The integration of GIS and interviews confirms the present situation of study areas in relation to changes (increase, decrease and change in quality) in the total and partial green spaces within a city.

The use of the 2D/3D GIS Model in the analysis was of great importance for the observation and mapping of the elements present in the geographic space. The data was represented dynamically, along four decades (1960-2013), through the association of data and the interpretation of clear and efficient spatial information. This processing of the quantitative data aims to create a 3D GIS model over the terrain, and locate visually the information for surface characterization. The result of this stage includes above-ground spatial objects. This first step was taken with most recent data available of Boa Viagem Beach (2013) and Rocha Beach (2010). This process is the basis for the reconstruction of the other years in this study. Through this technique it is possible to see in the previous aerial coverings whether or not the space objects of the study existed, and thus model the terrain.

Applications to verify vegetation-related variables and indexes is common within the Remote Sensing science, to quantify the spatial distribution of vegetation through the digital data of reflecting spectral bands. The surface of plants absorbs radiation in the visible range (between 0.4 and $0.7 \mu \mathrm{m}$ ) and is reflected in the Near Infrared (NIR) range (0.725 to 1.10 $\mu \mathrm{m})$. Thus, a vegetation index may be the ratio of the difference and/or combination between the VIS and NIR reflecting values, considering there is no atmospheric interference. However, in this paper, the data acquired in the public agencies consulted for this research will be 
used. The interest is the use of green areas for improvement of both cities' life and environmental quality. Another aspect is the use of terminology: green areas rather than green spaces. This last term is used for the denomination of all green spaces within the city (...). Green areas are specific to gardens or public parks only.

\section{RESULTS}

The analysis of land use in Boa Viagem Beach and Rocha Beach shows that these two urban areas, though in different countries, have similar problems in respect to green areas. Both study areas have consolidated gardens and parks, but they are little used by the population (local residents or tourists). This analysis in large scale shows that in the two areas, streets are made to benefit the cars. The pavement does not exist or is uncomfortable for pedestrians walk. Bicycle lanes are present at the beachfront, with little planning, and were built over the pavement, reducing available space. These observations can be seen empirically in both the study areas. On the other hand, contact with the local reality shows other aspects that are not perceptible at first sight.

Boa Viagem Beach has no trees on the sand, but has some coconut trees that provide limited shade, much used by local formal and informal beach commerce (beverages and snacks). The presence of coconut trees provides some relief from the sun until the early afternoon, after which buildings shade the beach (backshore). This is the reason why green areas have been used for moderating urban climate all over the world in recent years. Also, coconut trees are responsible for providing the feeling of tropical beach that sellers want to associate with their products. Therefore, in addition to physical comfort, they compose a landscape in agreement with users' desires, promoting psychological well-being.

Portugal has a longer history in relation to the planning of its coast when compared to Brazil. The first instrument is the Royal Decree of December 31, 1864, which establishes the Public Maritime Domain (MPD). This is now reflected in ever-changing and evolving models for the development and management of the coast, especially in continental Portugal. At Rocha Beach, commerce is well-organized and follows norms from the Coastal Zone Management Plans (POOCs) (Decree 309/93). However, relative to green areas, there is no specific regulation, and it approaches the same vulnerable situation as Boa Viagem Beach.

The green areas in Boa Viagem Beach are small patches, and a major area of mangroveflooded swamp that recedes rapidly at the rear of the neighbourhood. At Rocha Beach, there are four green areas (Fig. 2). These are the most representative green areas that were detected in both study areas. A more detailed work scale could reveal individual trees on the pavements, flower/grass beds along avenues and around buildings used by residents and tourists. However, the objective of achieving better urban environments does not result from individual trees and grass beds, but from the maintenance of much larger patches with full ecological services being provided to the surrounding city. In both study areas, it is shown that these significant spaces are shrinking rapidly, in the timescale of less than a lifetime, to make room for more buildings and roads (Fig. 3), which could already permanently compromise the quality of life of the present and next generation.

In relation to the interviews, the decrease in green areas and environmental quality was a transversal preoccupation across all involved from both study areas, independent of their profile in relation to urban changes.

'This is an aspect (green areas) that concerns the public sector. However, the real state sector, the population, and even researchers, agree that it does not serve public use, but the maximization of business interest' IBVB5. 

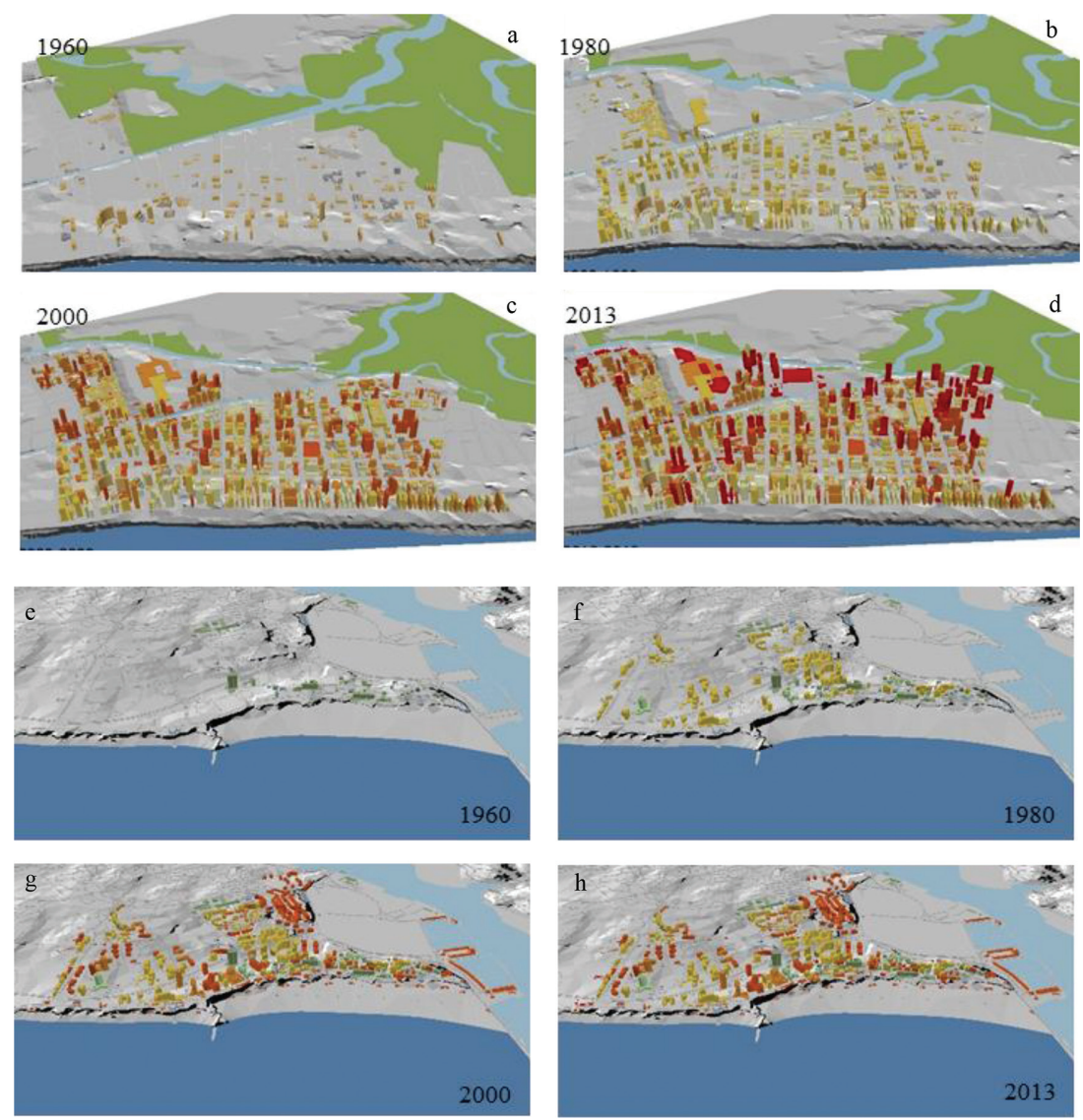

Figure 3: Evolution of vertical growth and green areas from 1960 to 2013 in (a-d) Boa Viagem Beach and (e-h) Rocha Beach. The different colours of the buildings represent their years of construction.

The common opinion is that green areas are essential to moderate air temperature change and that they are good for sports activities. Another aspect is the conviction that the creation/construction/maintenance of these green areas is the responsibility of public authorities exclusively.

The Intervieweds, in the public power, when questioned about this fact they always answered that 'the public administration should work to benefit the population, but the new administration is failing to promote change concerning green areas' IRB10, thus the government know the problem, but the actions of different administrations do not resolved the problem.

The associated question in Boa Viagem Beach answers that this is less important; for them the problem is related to public power and real estate. 'The public administration counts on the assistance of residents who seldom do the right thing about the building of green areas on their properties. They plant a couple of trees and a bit of grass where no one else has access' IBVB 07. 'Local regulation demands all new property to have at least $10 \%$ of green area' IBVB15. This shows that for the associations there is complicity relationship between the 
government and real estate. This work that make associate management, which is normally disregarded by planning authorities, is important for urban planning. The city organization is the result of the contribution of all those involved.

The real estate group are more pragmatic and say 'real estate always does what is determined by public regulation... If semi-permeable pavement is more convenient for parking areas, it will be used since this type of finishing is considered a green area' IRB01. In another place, about of the similar theme 'we have to think better about the city. Today, Recife is going through a complicated urbanization process. The government alone is unable to manage the city. We, real estate businessmen, can help as partners. But there are many things we have to do, for example, forbid homeless people to build in green areas (over land and water) or to invade public and private property' IBVB11. Here, the concern is of the real estate not the green areas or the comfort of the population, but that business has protection from the public power.

Local people have another consideration, because this group live with all the time. 'The population suffers from the absence of green areas, having no place to go in the neighbourhood for a walk or a dip, the only option being the sea. I was in Barcelona last year, and walked along a reorganized area near the beach ... There was a large park with playgrounds, trees, jogging track ... I thought the same could be made here in Boa Viagem, and other areas in our neighbourhood' IBVB13. Here the local people show disenchantment with the use of the city as a commodity. 'It occurs because the city's green areas are used for real estate speculation. People are often deceived when buying an apartment. The whole idea is that the surrounding landscape will never change. But, in reality, after they sell, the public administration suddenly becomes responsible for the view' IRB14. This is happens because the real estate speculators have no control, and the interest is higher than the welfare of local residents.

Criticism of the system is interpreted by research groups: 'Even with all the technology and space available, the public administration has no interest in building parks and taking good care of them... There are many places around Recife that are totally abandoned, or under-used as natural urban habitats, except for irregular activities and drug abuse' IRB15.

\section{DISCUSSION AND CONCLUSION}

The present work created an opportunity successfully to link ground data (quantitative) and perceptions from different and relevant participants (qualitative). This is important, as a link between these two types of information needs to be made, preferably at the planning stage of coastal cities and their neighbourhoods. Residents, living in the urban space or studying its changes, are the best agents to spot opportunities for land use, and to translate it into social welfare. Their sensibility could be used to locate housing, infrastructure and green areas.

The continuing increase in the number and size of cities and the ensuing transformation of natural landscapes on different scales pose significant challenges for reducing the rate of biodiversity loss and related ecosystem functioning, and ensuring human welfare [2, 9the provision of urban green areas is approached from a social perspective, as public spaces for recreation and sports activities, regardless of the environmental and economic benefits they can provide from a sustainable development perspective. The planning of urban green areas requires a set of conditions in order to be successful, among which are: an updated regulatory framework, adequate financial resources, technical knowledge of the appropriate plant species and the effective participation of the community. However, without a complete and classified inventory of the existing green areas, any planning is unfeasible. 
The term

'green areas' in the cities this study is a mistake, the correct use this term 'green areas' should be related to gardens, parks with plants, animals and microorganisms. This biodiversity can be used by residents of the zone and the ecosystems, and the services that they can provide.

Urbanisation and soil-sealing provoke changes, predominantly a decline, in species diversity and human well-being in cities [2]. Other types of change - vegetation in urban areas - can be reoffered as green spaces (e.g. trees, grams, bush and flowers beds in avenues or private buildings). Therefore, there should be a different classification for green areas in the two studies. Certainly there would be a better notion of what use they would be to residents. For example, the study area of Rocha Beach is presented without green spaces (Fig. 4). Note that there are only four green areas for use by residents. However, only two gardens are open to residents (on the beach cliff, and to the north of the study area). The other two areas are on private land without access to inhabitants (the east) and the last was granted to the town hall to build a park with other general public facilities (soccer field, basketball, tennis, among others).

Another important aspect in that have attention is the evolution of the transformation of natural landscapes, is the fact of Boa Viagem Beach (Fig. 3). The urban vertical growth was rapid and destroyed the coastal landscape. The mangrove swamp disappeared, with the years

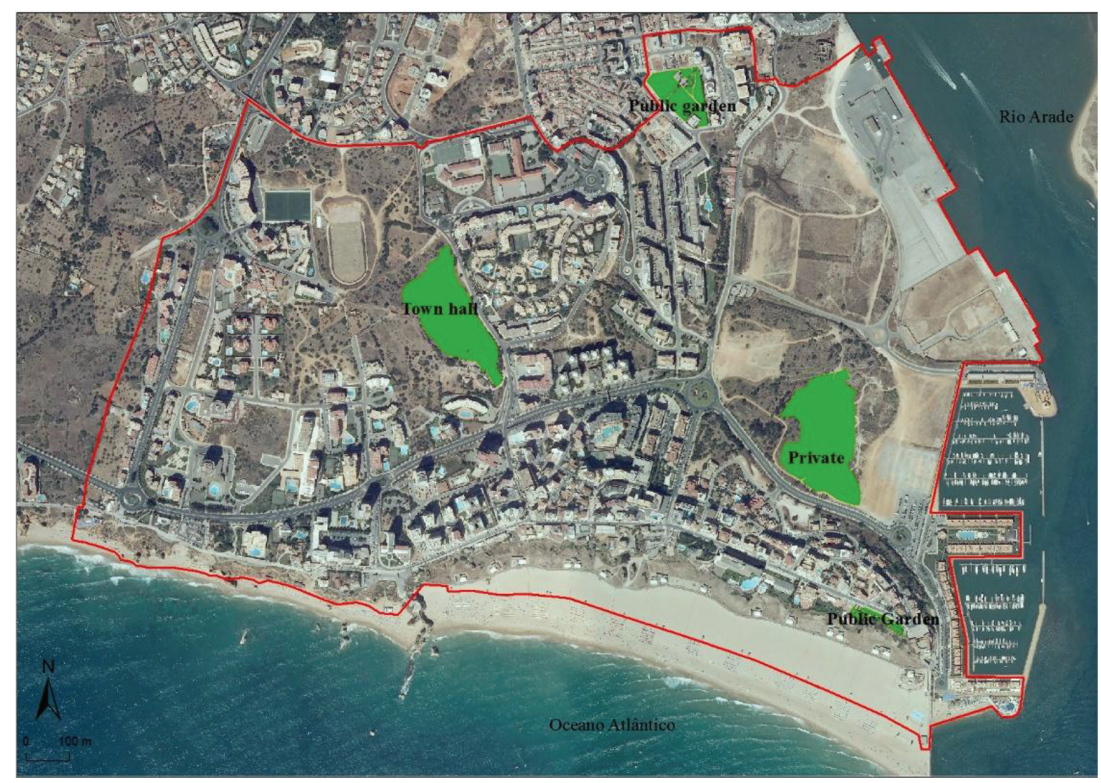

Figure 4: The study area of Rocha Beach whit the useful green areas. 
and the construction of urban buildings. The result, as pointed out in the semi-structured interviews, was the creation of a cluster of skyscrapers that today constitute a complicated urban arrangement. The Secretariat of Environment and Sustainability of the City of Recife has classified all green spaces so that the calculations of the green areas (Table 2) obtain a high index figure; but if one looks closer, to the local reality we see that in the area of study of Praia de Boa Viagem has almost no green areas, and those that might be possible are in a very bad state of preservation.

The importance of the 'green areas' study is related to improving the quality of life of the inhabitants. Many point out that green areas provide ecosystem services, which include reduction of air pollution, reduction in the heat island, benefits to health (which make cities more sustainable), and with the use of the green areas inhabitants are more sociable.

Lastly, it can be emphasized that the use of the term 'green areas' deserves to be highlighted as note for a correct use for a better designation of these areas, in the cities and especially in the coastal zones. Thus the elaboration of the indices of green areas could be better represented and adequate the reality. Another important aspect of green areas should also include qualitative use and constant conservation.

Considering the complexity of today's society, exposed to increasingly artificial environments, the urban planning should find seek solutions ways to prevent the decline of environmental quality in the city in general and special attention of coastal zones. Coastal areas, as pointed out by the interviewed, require regular greater environmental comfort protection, and with larger green areas for the leisure and sociability and pleasure of appreciate the views and the nature by the inhabitants and tourists. This study approaches the analysis of green areas in two different countries and contributes to the knowledge and possible improvement of the conditions quality of life of the two cities.

\section{ACKNOWLEDGEMENTS}

MGM thanks CAPES - Brazilian Ministry of Education for the PhD scholarship. MFC is a CNPq Fellow. RFD is a FCT PhD and EMR is a FCT Post-doctoral.

\section{REFERENCES}

[1] Dasgupta, S., Gosain, A.K., Rao, S., Roy, S. \& Sarraf, M.A., Megacity in a changing climate: the case of Kolkata. Clim Change [Internet]. 2012 Jun 28 [cited 2013 Aug 16]; 116(3-4), pp. 747-766, available at http://link.springer.com/10.1007/s10584-012-0516-3 https://doi.org/10.1007/s13280-014-0504-0

[2] Haase, D., Larondelle, N., Andersson, E., Artmann, M., Borgström, S., Breuste, J., Gomez-Baggethun, E., Gren, Å., Hamstead, Z., Hansen, R. \& Kabisch, N., A quantitative review of urban ecosystem service assessments: concepts, models, and implementation. Ambio, 43(4), pp. 413-433, 2014.

[3] UNDESA. World Urbanization Prospects: The 2011 Revision [Internet]. Presentation at the Center for Strategic and ... 2012, available at http://esa.un.org/unpd/wpp/ppt/ CSIS/WUP_2011_CSIS_4.pdf

[4] Magarotto, M.G., Costa, M.F., Tenedório, J.A., da Silva, C.P., Vertical growth in a coastal city: an analysis of Boa Viagem (Recife, Brazil). Journal of Coast Conservation [Internet], 19(52), pp. 1-12, available at http://link.springer.com/10.1007/s11852-0150415-7 
[5] Inouye, C.E.N., de Sousa, Jr. W.C, de Freitas, D.M. \& Simoes, E., Modelling the spatial dynamics of urban growth and land use changes in the north coast of São Paulo, Brazil. Ocean Coast Management, 108, pp. 147-157, 2015. doi:10.1016/j.ocecoaman.2014.12.016

[6] Mikovits, C., Rauch, W. \& Kleidorfer, M., Dynamics in urban development, population growth and their influences on urban water infrastructure. Procedia Eng [Internet]. Elsevier B.V.; 2014 [cited 2014 Oct 22];70, pp. 1147-1156, available at http://linkinghub.elsevier.com/retrieve/pii/S1877705814001295

[7] Wong, N.H. \& Yu, C., Study of green areas and urban heat island in a tropical city. Habitat Int [Internet], 29(3), pp. 547-558, 2005, available at http://linkinghub.elsevier. com/retrieve/pii/S0197397504000281 https://doi.org/10.1016/j.habitatint.2004.04.008

[8] Santos, T., Tenedório, J. \& Gonçalves, J., Quantifying the city's green area potential gain using remote sensing data. Sustainability [Internet], 8(12), p. 1247, 2016, available at http://www.mdpi.com/2071-1050/8/12/1247 https://doi.org/10.3390/su8121247

[9] Peña-Salmón, C., Leyva-Camacho, O., Rojas-Caldelas, R., Alonso-Navarrete, A. \& Iñiguez-Ayón, P., The identification and classification of green areas for urban planning using multispectral images at Baja California, Mexico. In: Ecology and the Environment [Internet]. pp. 611-621, 2014, available at http://library.witpress.com/viewpaper. asp?pcode=SC14-051-1

[10] Balram, S. \& Dragićević, S., Attitudes toward urban green spaces: integrating ques tionnaire survey and collaborative GIS techniques to improve attitude measurements. Landsc Urban Plan [Internet]. 2005 Mar [cited 2015 Oct 26];71(2-4), pp. 147-162, 2005 available at http://www.sciencedirect.com/science/article/pii/S0169204604000520

[11] Barros HR, Lombardo MA. A relação entre ilhas de calor urbana, ocupação do solo e morfologia urbana na cidade do Recife. Rev GEONORTE [Internet], 2(5 Especial 2), pp. 65-76, 2012, available at http://www.revistageonorte.ufam.edu.br/attachments/013_\%2528A RELA\%25C3\%2587\%25C3\%25830 entre ilhas de calor urbana, ocupa $\% 25 \mathrm{C} 3 \% 2587 \% 25 \mathrm{C} 3 \% 2583$ o do solo e morfologia urbana na cidade do recife $\% 2529$.pdf

[12] Folke, C., Hahn, T., Olsson,P.\& Norberg, J.,Adaptive governance of social-ecological systems. Annual Review of Environment and Resources [Internet], 30(1), pp. 441-473, 2005, available at http://www.annualreviews.org/doi/abs/10.1146/annurev.energy.30.050504.144511 